【Currrent Views】

\section{一般臨床医とパラメディカル に対するサプリメント 知識習得のすすめ}

\section{A Recommendation for the} Acquisition of Knowledge of Natural Health Products (NHP) for Physicians and Paramedical Staff

\author{
谷川啓 司 $1,2, *$ \\ Keishi TANIGAWA ${ }^{1,2, *}$
}

1 ビオセラクリニック 院長

${ }^{2}$ NHPインターナショナル認定機構 理事長

\section{【要 旨】}

最近治療補助だけでなく，疾病予防・健康保持を目的 にサプリメントの利用者は急増している。しかし，食 品に分類されていても様々な薬理効果を持ち, 健康管 理をする側から無視できない状況となってきた. しか し, 医療従事者にはサプリメントに対する意識が薄く， また知識も持ち合わせていない，今回紹介する MSA 認定講座は, EBM に基づいたサプリメント情報を疾病 からアプローチしながら学ぶ，医療従事者を対象とし た上級講座である。臨床で働く医師也薬剤師等が信頼 しながら学びやすく考慮された内容で, 臨床的な応用 を念頭に配慮された構成になっている. また利用者の 利便性を考慮し, 受講は e ラーニングシステム, 資格 認定試験は CBT システムを導入している. 今後, 氾 濫するサプリメントの情報の中で正確なものを見極め る力を養い, 総合的な医療として，サプリメントも利
用した健康管理を臨床の医療従事者がリードして行っ ていくことが望まれる.

$$
\begin{aligned}
& \text { 【キーワード】 } \\
& \text { メディカル・サプリメント・アドバィザー, サプリメ } \\
& \text { ント, ナチュラルヘルスプロダクト e ラーニングシ } \\
& \text { ステム, CBT 試験システム }
\end{aligned}
$$

\section{I. はじめに}

現在診療に携わっている医師の中で，サプリメントや 健康機能食品等について質問を受けたことのない方は括 そらくいないであろら。

私は消化器外科医として始まり，1996 年からは本格的 に先端医療としてのがん免疫細胞療法に携わることに なった。 そして現在では免疫細胞療法, 温熱療法といっ たものを取り入れながら，総合的ながん治療を目指して 臨床活動をしている．この診療領域では，実に多くの患 者や家族から食事療法や健康食品といった代替医療に関 するアドバイスを求められる，そらいった代替医療がす でに罹患しているがんに対して，薬理学的に高い効果を 示すかぞらかは懐疑的である。しかし，患者側の立場と して宣伝で紹介されている症例を見れば，たとえわずか であっても効果が認められるものがあれば取り入れたい と思うのは当然である。また私が免疫細胞療法とは別部 門として行っている一般診療に扣いても，生活習慣病等 の領域でのサプリメントに関するアドバイスを求められ ることも非常に多くなった。

最近では病気に関するテレビ番組や雑誌の特集なぞも 多く，患者の病気に対する意識は高まり，それと同時に サプリメントの宣伝も頻繁に行われている，患者はサプ リメントを処方のいらない，簡単に摄取可能な一種の治 療のごとく感じていることも多い，その結果，宣伝の内 容を医師に確認したくて質問してくるといらことが多い ようだ。またこれらのマスコミや宣伝の効果は，治療の 必要がない患者飞も影響を与光, 病気予防や健康増進を 目的としてますます取り入られるようになった。

今後ますますサプリメントを利用する人が増えること が予想される. しかし, 大学教育や卒後の研修を含めて, 多くの医療従事者にはこのような知識を学ら゙機会は活と んぞない，今後は患者側の要求に十分応えられるような 知識や必要な情報を，自らが効率よく入手することが求 められる時代になったと思われる。 


\section{II. 医師がサプリメントの知識を持つことの意義と必要性}

\section{（1）サプリメント使用は患者の能動的な健康管理意識の} 表れ

私は診療内容の特殊性から患者や家族と長く話寸機会 が多く、これまでの治療に打ける患者側の不満を聞くこ とが多い. その大半は医師の説明やコミュニケーション 不足から生じる心理的解離による. がん患者の多くは強 い精神的不安を持ちながら闘病生活を送っている。この 心理的不安感は睡眠不足・食欲低下など生じさせ，結果 的に体力低下・抵抗力低下を起こして治療効果を下げる ことにつながる。この心理的不安を除くことが治療効果 の改善や QOL の改善・維持につながる可能性は指摘さ れている通りである.

しかし，担当医にサプリメントを含む代替医療全般の 相談した時に，頭ごなしに否定された場合などは，医師 と患者や家族との心理的な溝を生じ，治療上の障害にな ることも少なくない．特に行っている治療の効果がな かったと判定された説明を受けた時には，自分たちの提 案は否定され，医師の言う通りにしても効果はなかった ことになる.この場合の医師の説明や対応により，患者 や家族は疎外感・絶望感を持つだけでなく，医師に対し て憎悪感を持たせる場合もある.

がん患者側は医師から受けている治療効果以外に，わ ずかでも効果をもたらす「何か」を望んでいる，それは 通常の治療の上うに医師からの受動的な子のではなく, 患者の側が自分で調べて行ら能動的な対応の表れなので ある、その一つがサプリメントの使用なのであろう。こ のような，患者側の積極的で前向きな気持ちを否定する ことで患者にあたえる精神的な影響は非常に大きいと考 えるべきである.

この内容はがん治療に限らず，一般診療に执いても同 様のことが言える．すなわち，サプリメントや健康機能 食品などの摂取は健康管理に関する患者サイドの積極 的・能動的な対応であり，この気持ちをくんだ形での健 康管理が求められているのである。 サプリメントの使用 は自分が健康でいたい，治療の補助にしたいといら患者 側の強い訴えであり，これらを抑えてしまったり無責任 な対応を取ったりすることは，健康管理をする我々医師 にとってあってはならないことであることを認識するべ きである.

\section{（2）サプリメントはたかが食品という認識では危険}

医師がサプリメントに関して受ける相談は，打括むね 以下の 2 点に集約される.

(1) : 現在罹患している疾患に対する補助作用としての利
用

(2) : 健康の維持・増進や病気予防（未病）としての利用 現在のところ，日本の医学教育には系統的なサプリメ ント等の教育は行われていない.したがって, 興味を持っ て医療従事者が自ら習得しなければ，あまり深い知識を 持つことはない，しかし，知識を持たないことで，「たか が健康食品」といった安易な答えをすることで，問題を 引き起こすことはある.

上記の(1)のよな状況で，利用しているサプリメント に対してのコメントを求められた時に，あまり関心を持 たずに「大丈夫である」と言ってしまいがちな状況がよ くある。しかし，そのサプリメントと現在治療中の疾患 との関連に注意を払わずに，併用を見逃していると，大 きな問題が生じる場合もある. 独立行政法人 国立健康・ 栄養研究所の「健康食品」の安全性・有効性情報1)を参 考にしていただければ，安易な答えの危険に気づくこと ができる、いわゆるサプリメントの中にはかなりの薬効 成分を含むものがあり，これらが人体に与える影響を無 視できない.つまりサプリメントといえども，医師が行っ ている治療を増強させることもあれば，減じたりさせる ものもありらるのである。したがって治療薬を処方しな がら効果をみている一般診療医にとって，サプリメント の使用が治療の効果判定や治療スケジュールに影響を与 える可能性は十分にある.

現在の医療機関では，治療の補助的効果を目的とした サプリメント指導は通常行われていない，せいぜい一般 的な食事療法と運動指導などであり，細かなサプリメン トの内容になれば一部の専門家を除けば敬遠しがちと思 われる。そこには，「たかが食品」といら甘い認識や，そ のことを指導することの正当な医療指導料といったもの が確立されていないことにもあると思われる.

しかし，「たかが食品」という考壳では見逃せない有害 事象も抗こりらることを，我々医師が十分認識するべき である。こういった関連商品により通常の処方薬の効果 が増強されたり，抑えられたりすることもあれば，この 食品の管理があまりにもいい加減であれば治療薬の処方 とその副作用にも影響を与兄ることもある。国民生活七 ンター2)や国立健康・栄養研究所などのホームページ有 害事象を参照すれば，これまでに質問された内容が含ま れていると思わ机ることも多いと思われる。

\section{（3）情報摂取の必要性}

以上のことょり一般診療を行っている医師や医療機関 の側であっても，今後ますます増加するサプリメントを 含む社会環境に即した知識を要求される.しかしながら， すでに現場で医師として働いているものにとって，系統 
だった知識の習得は容易ではない，私たち臨床医にとっ て必要なサプリメントの知識といったものは以下のよう なものと考光る。

1：サプリメントといえども人体に影響を与えたり，治 療効果に影響を与えたりする可能性があることを十 分認識すること

2：サプリメントについての概略を病態薬理学的な機序 にのっとって把握できるとともに，必要時に調べる ことができる環境を整えておくこと

3: 未病といら予防医学の立場に立って, 臨床症例に即 した学習する機会をなるべく多く持つこと

こういった知識を，臨床に携わる医師や医療従事者と して, 系統的に学習, 情報を更新していく機会が必要で あると思われる。

\section{III. サプリメント知識を系統的に習得するための講座}

現在，サプリメント関連の知識を習得する講座は表 1 に示すようにいくつか存在している. これ以外にもイン ターネットで検索すれば, 容易に知ることは可能である. これらの講座でも, 特定保健食品などを中心として栄養 学や法律的な解釈を中心にしたものから，いわゆる製造 や販売の業界との関連による講座まで多様である.

しかし，目的は様々であるが，これらの講座は法的規 制が効きにくい「食品」に分類されるものが，日本国内 で無秩序に使用されないように，特定の立場の人間にサ プリメントの知識を習得させようと生まれたものであ る. 今回私が強く感じている, 臨床医としてのサプリメ ント知識の習得は，扮そらく何を媒体にして学んでも，
最終的には可能だと思われる。しかし，すでに臨床現場 で働く医師や他の医療從事者が実用的なサプリメントの 知識を習得するためには，臨床面に沿って系統的に学べ るように工夫された講座が早道であると考光る.

その点，今回紹介させていただくメディカル・サプリ メント・アドバイザー認定講座 ${ }^{3}$ は，一般的に診療に携 わっている医師や医療従事者がサプリメントを臨床的な 立場から習得するのに適したものである。講座の進行は サプリメントを病態薬理学的なアプローチから入ること で理解しやすく，また一般的な処方薬などとの因果関倸 も把握しやすい，日常診療に即した医師や薬剂師などの 臨床的業務を行うものにとって学びやすく，また日常診 療でのアドバイスに直結するものと考えて応援させてい ただいている。

\section{（1）メディカル・サプリメント・アドバイザー認定講座 とは}

このメディカル・サプリメント・アドバイザー（以下 MSA）認定講座は医師・薬剂師といった医療従事者（有 資格者）を対象として，サプリメント知識を習得させる ための上級講座である。サプリメントは今後, 病気の予 防と健康の維持としての主役となる時代になりつつあ る。そこでサプリメントの医学的な効果等を医師・薬剂 師といった医療従事者がリーダーとなって患者に説明し ていく必要性のために生ま机た。

この講座の一番の特徵は, 世界での臨床試験の結果か ら，すなわち Evidence based medicine (EBM) に基づいて, サプリメントの安全性，有効性，作用メカニズム，副作 用，禁忌等の情報を学ぶことができることである。この

表 1 さまざまなサプリメント関連知識の習得講座

\begin{tabular}{|c|c|c|}
\hline 認定主体 & 資格名称 & 要 \\
\hline $\begin{array}{l}\text { 日本サプリメントアドバイザー認定機構 } \\
\text { (日本臨床栄養協会内) }\end{array}$ & サプリメントアドバイザー & $\begin{array}{l}\text { ・栄養学 公衆衛生学・国内外の関連法規 ・臨床薬理 } \\
\text { 学・食品学・食品機能学など }\end{array}$ \\
\hline 国立健康・栄養研究所 & 栄養情報担当者 (NR) & $\begin{array}{l}\text { ・栄養・食品学特論・食品表・栄養教育論など・臨床医 } \\
\text { 学・学特論・栄養・食生活と生活習慣病 ・食品の安全 } \\
\text { 性と衛生管理 }\end{array}$ \\
\hline 日本ニュートリション協会 & サプリメントアドバイザー & $\begin{array}{l}\text { ・ビタミンとは何か・ミネラルとは何か・ハーブとは何 } \\
\text { か・ハーブの効用・サプリメントとは何か・活用のため } \\
\text { の基礎知識・スポーツサプリメント・・薬事法・訪販法・ } \\
\text { サプリメンアドバイザーの営業活動など } \\
\end{array}$ \\
\hline 新生活普及協会 & $\begin{array}{l}\text { サプリメント管理士 } \\
\text { サプリメント管理士マスター }\end{array}$ & $\begin{array}{l}\text { ・ビタミン, ミネラル, ハーブなどの基礎知識・関連法規 } \\
\text { など }\end{array}$ \\
\hline 日本チェーンドラッグストア協会 & ヘルスケアアドバイザー & ・体の構造と働き・関係法規・制度など \\
\hline 全日本健康自然食品協会 & 食養士・管理食養士 & 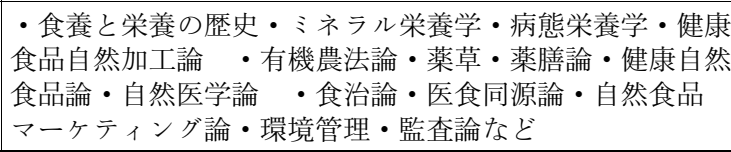 \\
\hline
\end{tabular}


講座の開発者であるカナダのアルバータ大学のヘシャッ ク教授は，カナダ政府のサプリメントリサーチチームの 第一人者として活躍されている方である.

ヘシャック教授のサプリメント教育は臨床試験の結果 やケーススタディなどを中心としたものであり，カナダ の全大学の医学部と薬学部に和けるサプリメント教育カ リキュラムの制作にも携わっている，そのーシャック教 授の行っているサプリメント教育が系統的にまとめら れ，さらに日本の薬事関連の法令や薬剤指定されている ものなどを除くなどの修正がくわえられた。まだあまり 教育が進んでいない日本に打いて，医療従事者を中心に サプリメントを利用した健康管理を行らことを目的とし

て MSA 認定講座は考案された。

(2) ウェブ講座（e ラーニング）としての受講システム これらの講座は後述するカリキュラムを見れば分かる 上うに, 臨床的に 14 章から構成されて打り, 習得するべ き内容量も多い。すでに有資格者として日常の業務を 行っている医療從事者が, 講義に出向いて受講すること は困難を要す．現在，就労者を対象にした講習等では通 信教育がほとんどであるが，社会全体の IT 化により，イ ンターネットによる受講システム（e ラーニングシステ ム）が行光るようになった。 この MSA 認定講座も e ラー ニングシステムを導入している．すでに国内では多くの 医療機関がインターネットを導入し，また自宅まで含め ればインターネット環境が整っていないことは汪とんど
ないものと思われる.

e ラーニングシステムでは，時間のある時を利用して 受講でき,インターネット環境が整っていれば, 場所も 問わない，当然教材を持ち運ぶこともないため，条件が そろっている受講生には大変便利なシステムである。 ま たウェブページ内容をプリントして持ち運ぶことによ り，通勤などの移動中でも知識の習得は可能である。さ らに講座内リンクも充実しているため講座内の関連項目 への移動や，また他の一般検索もそのままインターネッ トを利用すれば可能である．視覚的にもカラーで表示さ れていることから，植物の写真なども鮮やかにみること ができる点でも印象に残りやすい.

全過程の予定終了機関は半年から 1 年を想定している が, 自分のペースで行えるので, 早く終了することもゆっ くり行うことも可能である. 実際に講義といった緊張感 がないものの, 受講者の都合にあった形で知識の習得が できる点で大変優れていると思われる.

\section{MSA 認定講座での講座内容}

この講座は一般診療をしている医師を中心とした医療 従事者には，大変受講しやすい工夫がされている，表 2 をみていただければ分かるよらに，講座のカリキュラム 内容は疾病を中心に順次学ぶように構成されている。対 象疾患はごく一般的に診療が行われている生活習慣病か ら精神的な疾患まで，近年増加し続けているものが多く

表 2 MSA 認定講座の受講内容カリキュラム

\begin{tabular}{|c|c|c|}
\hline 第 1 章 心血管病 & 第 7 章 肥満 & 第11章 スポーツ \\
\hline 1-A 高脂血症 & 7-A 肥満 & 11-A スポーツ \\
\hline 1-B 高血圧症 & & \\
\hline 1-C 弓っ血性心不全 & $\begin{array}{c}\text { 第 } 8 \text { 章 } \\
8 \text { 中枢神経系・他神経 } \\
\text { 万つ病 }\end{array}$ & $\begin{array}{c}\text { 第 } 12 \text { 章 アンチエイジング } \\
\text { 12-Aアンチエイジング }\end{array}$ \\
\hline 第 2 章 糖尿病 & 8-B 不眠症 & \\
\hline 2-A 糖尿病 & $\begin{array}{l}\text { 8-C } \text { 不安障害 } \\
\text { 8-D } \text { 痴呆症 }\end{array}$ & $\begin{array}{c}\text { 第 } 13 \text { 章 } \\
13-\mathrm{A} \text { 癌 } \\
\text { 乳癌 }\end{array}$ \\
\hline 第 3 章 感染症 & & 13-B 前立腺癌 \\
\hline 3-A 感冒とインフルエンザ & 第 9 章 胃腸疾患, 消化器疾患 & 13-C 結腸直腸癌 \\
\hline 3-B 尿路感染症 & $\begin{array}{ll}\text { 9-A } & \text { 消化性潰瘍 } \\
\text { 9-B } & \text { 消化不良・胸やけ・胃炎 }\end{array}$ & 13-D 肺癌 \\
\hline $\begin{array}{c}\text { 第 } 4 \text { 章 骨・関節疾患 } \\
4-A \text { 変形性関節症 }\end{array}$ & $\begin{array}{l}\text { 9-C 炎症性腸疾患（クローン病・潰 } \\
\text { 瘍性大腸炎） }\end{array}$ & $\begin{array}{c}\text { 第 } 14 \text { 章 } \\
14-\mathrm{A} \text { 痛み } \\
\text { 頭痛 }\end{array}$ \\
\hline 4-B＼cjkstart慢性関節リウマチ & 9-D 過敏性腸症候群 & 14-B 頭痛の予防 \\
\hline 4-C 骨粗鬆症 & $\begin{array}{ll}9-\mathrm{E} & \text { 便秘 } \\
9-\mathrm{F} & \text { 下痢 }\end{array}$ & \\
\hline 第 5 章 女性疾患 & 9-G 吐き気・嘔吐 & \\
\hline 5-A 更年期障害 & 9-H 肝疾患 & \\
\hline 5-B 月経前症候群 & 第 10 章 目の疾患 & \\
\hline $\begin{array}{cl}\text { 第 } 6 \text { 章 } & \text { 男性疾患 } \\
6-A & \text { 良性前立腺肥大症 } \\
6-B & \text { 勃起障害 }\end{array}$ & 10-A 黄班変性 & \\
\hline
\end{tabular}


含まれている。

まずは全体像を学ぶ必要があることから，第 1 章から 順番に受講しなければ，他の章に進めない上らに構成さ れている。 しかし一度全体まで履修しサプリメントの概 略をひと通り学んだ後は, 自分の診療上で直接関係ある 部位を中心に直ちに見直すことが可能である. 講座内容 は疾患の病態と治療の概略と作用メカニズムを中心にし た総論的な内容から，サプリメント療法としての各論的 な内容, さらにケーススタディと知識確認テストという ような構成になっている.

\section{（1）疾患における全体的な病態・治療の把握（総論）}

基礎知識として, 疾患の病態発生メカニズムや一般的 な治療法に加えて，よく利用されるサプリメントも紹介 されている.

この講座の優れたものの一つに作用メカニズム図解が ある. 疾患の病態メカニズムと薬剤・サプリメントがひ と目で把握できるように工夫されている。図 1 は第 1 章 の高脂血症の作用メカニズムの図解である。この図解に は体内での脂質代謝の流れと, 治療薬並びにサプリメン トの薬理学的な作用部位が同一画面上に示されているこ

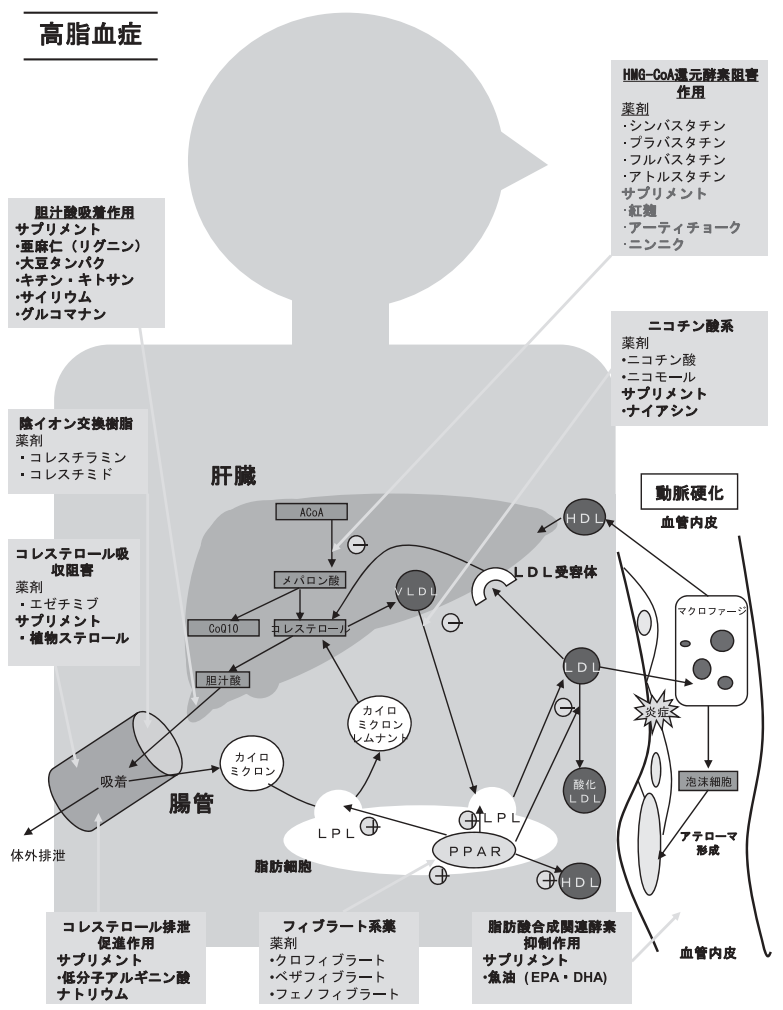

図 1 病態の発生機序と薬剂・サプリメントの作用部位 高脂血症に打疞態の発生機序と, 薬剂やサプレメントが作 用する部位が全体として理解しやすく画かれている.
とがわかる，例えば高脂血症で有効な紅责匊の成分が含ま 孔ているサプリメントを服用している場合には，その作 用が HMG-CoA 還元酵素阻害作用として働いている。そ こでもし，医療機関からスタチン系薬剤の処方を受けて いる場合には，その治療薬の有効量の判断に影響を与之 る可能性がある。 また同一な作用機序で効果を出す以上, 副作用も同様に生じることがある。仮にスタチン系薬剤 の副作用で処方を控えていても，このサプリメントを継 続して使用すれば，副作用も生じてしまうために状況把 握が困難になる。このような判断を行う上で，各種薬剤 やサプリメントの作用部位が同一画面で確認できること は非常に有益である.

\section{（2）各サプリメント療法の解説}

各論としてのサプリメント療法では，まずはその個々 のサプリメントについての作用メカニズム，摂取方法， 副作用，使用上の注意，相互作用に加えて，最後に臨床 試駼結果を含めた臨床エビデンスについての解説，さら に全体的な結論としてサプリメント有効性を統括すると いら形をとっている．図２に全体的な雾囲気を見ていた だくためにウェブページ上の内容を単純化させたものを

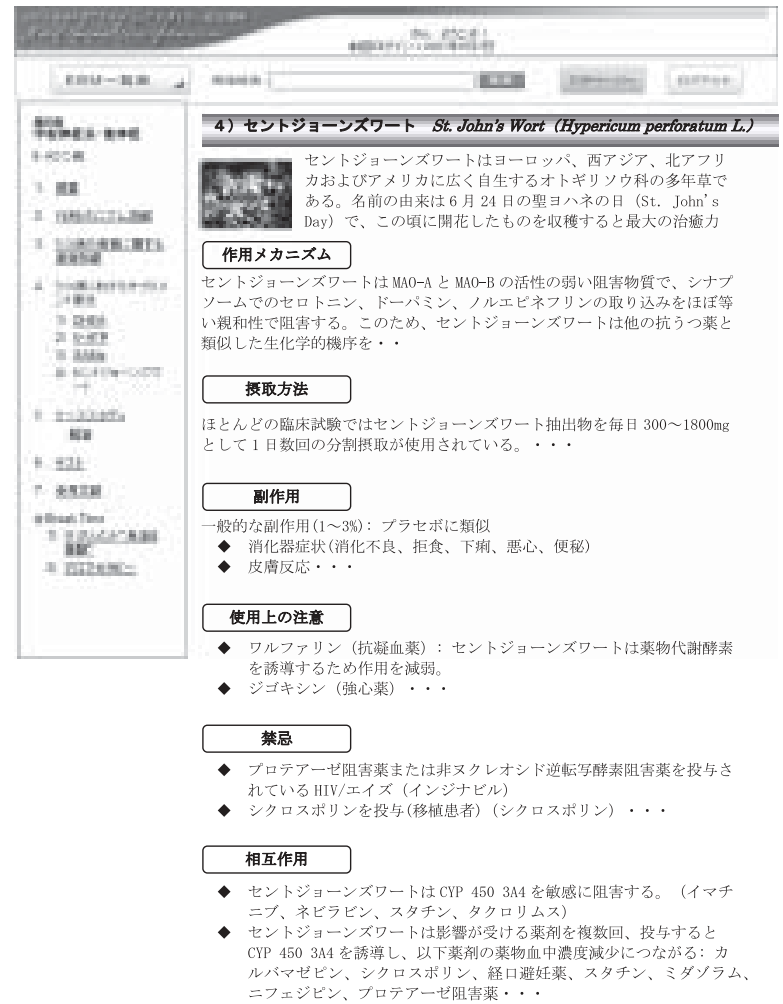

図 2 Web Page 上で見られるサプリメント療法各論部分の概略 疾患に有効とされるサプリメントについてその作用メカニズ ム, 摂取方法等が説明されている. 
示した. これは第 8 章のらつ病に有効とされるセント ジョーンズワートのサプリメント療法について示した ページである。 この図からわかるよらに，作用メカニズ ムでは薬理学的な解説を詳しく示して扣り, また摂取量 としてどれくらいの量が効果を示すかなども記載されて いる．したがって，サプリメント内の成分量がどの程度 で有効量になるのかといった判断にもなる。このサプリ メント自体の薬理学的なアプローチが理解されていれ ば, 副作用, 使用上の注意, 禁忌, また他の薬剤との相 互作用といったものも理論的に納得しやすいようになっ ている.

\section{（3）臨床試験の結果の紹介による信頼性の高い説明}

この講座のもっとも象徵的でかつ有意義なものがこの 臨床試験の結果の紹介, 臨床エビデンスである. サプリ メントは食品だといら安易な考光は, 医学的に検証され ていないといら勝手な思い込久から来ることが多い。し かしながら海外ではこらいった代替医療も研究対象とし て検討されて打り, 大規模な臨床試験も行われている. 個々の臨床試験の結果やそれらを利用したメタアナライ シス解析等をみれば，そのサプリメントの疾患に打ける エビデンスレベルを知ることができる.

また全体的結論の項では，そのサプリメントの有効性 が信頼性や客観性を含めた全体的な評価をコメントとし て載せてある。これは現時点での利用の有無についての 判断をする時に役立つと思われる.

図 3 は臨床エビデンスの部分を抜粋したもので，炎症 性等疾患に対する魚油についてのサプリメント療法を示 したものである。この臨床エビデンスの項から，この疾 患に対する魚油を用いたランダム化された臨床試験子規 模の大小はあるが行われて扔り, 臨床試験の結果からの レビューやメタアナライシス解析された論文も出ている ことがわかる。こうした結果はサプリメントの有効性を 判断するにあたり非常に有用である.

さらに最後の全体的結論では，そのサプリメントにつ いて, 研究デザインも含めた臨床試験の信頼性や，医学 的に有效性が認められるのかぞうかといった点について のコメントもある．短時間でそのサプリメントの信頼性 を判断するためにはこの部分を参照するだけでも非常に 有益であると考える.

\section{(4) ケーススタディからの実践的なサプリメント指導}

この講座のもら一つの特徴的な内容は, 実際に臨床の 場を想定したシミュレーションである。一般的な状況を 想定し，症例提示として患者の主訴や治療内容等が説明 されており，これに加えて代替医療をいかに利用してい

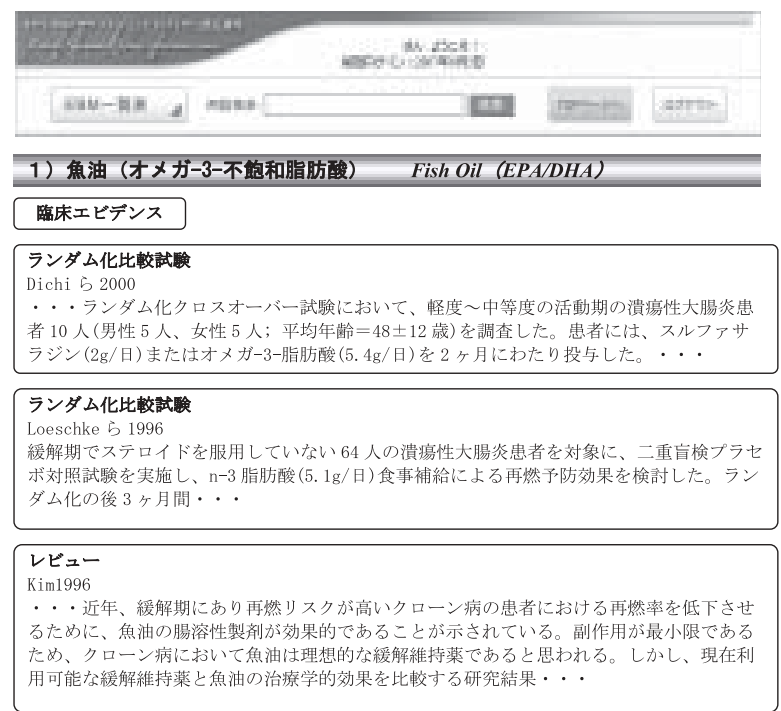

\section{ランダム化比較試験}

Belluzzi ら 1994

…多くの厄介な副作用(すなわち、おくび、口臭、下痢等)が患者のコンプライアンス に影響を及ぼす。本試験は、クローン病 $(\mathrm{CD})$ 患者群を対象として、エイコサペンタエン酸 ードコサヘキサエン酸(EPA 40\%-DHA 20\%)の 500mg カプセル剂、遊離脂肪酸混合物 (Purepa) からなる新規の魚油派生物に対する患者の耐容性を・・・

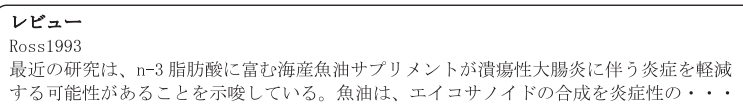

\section{全体的結論}

標準的な治療法にオメガー3 不飽和脂肪酸を加えた場合に、その炎症に対する効果が潰 瘍性大腸炎およびクローン病の患者に有益である可能性が示唆されており、この分野 でいくつかの試験が実施されている。これまでの結果は有望なものであるとはいえ、 大半の試験は・・・

図 3 サプリメント療法に打ける臨床エビデンスの例 サプリメントの効果を示した臨床研究の結果やレビュー, メタ アナライシス解析等とその全体的な結論が示されている.

くかを考光させられるよらなパターンとなっている。こ のようなケーススタディでは実際にサプリメントを含め た治療計画を，何を問題点とし，治療の目標，代替医療 を含めた治療法の全体, ぞういったアドバイスをするか, ぞのように経過を観察するべきか，などといった臨床に 即した対応を質問形式に示している.

図 4 に一例を示した．これは高血圧患者に対するヶー ススタディである.内容的にはあくまでもサプリメント 専門家を想定している診療シミュレーションであるが, 実際の診療についても医湾同様であることは理解でき る. このシミュレーションに対する解答例はもちろん, ウェブ講座上で示されている。 しかし，あくまでも一つ の解答例であり, 我々が学ぶ場合には臨床家として一定 の判断基準のもとで作り出していくべきものである. 


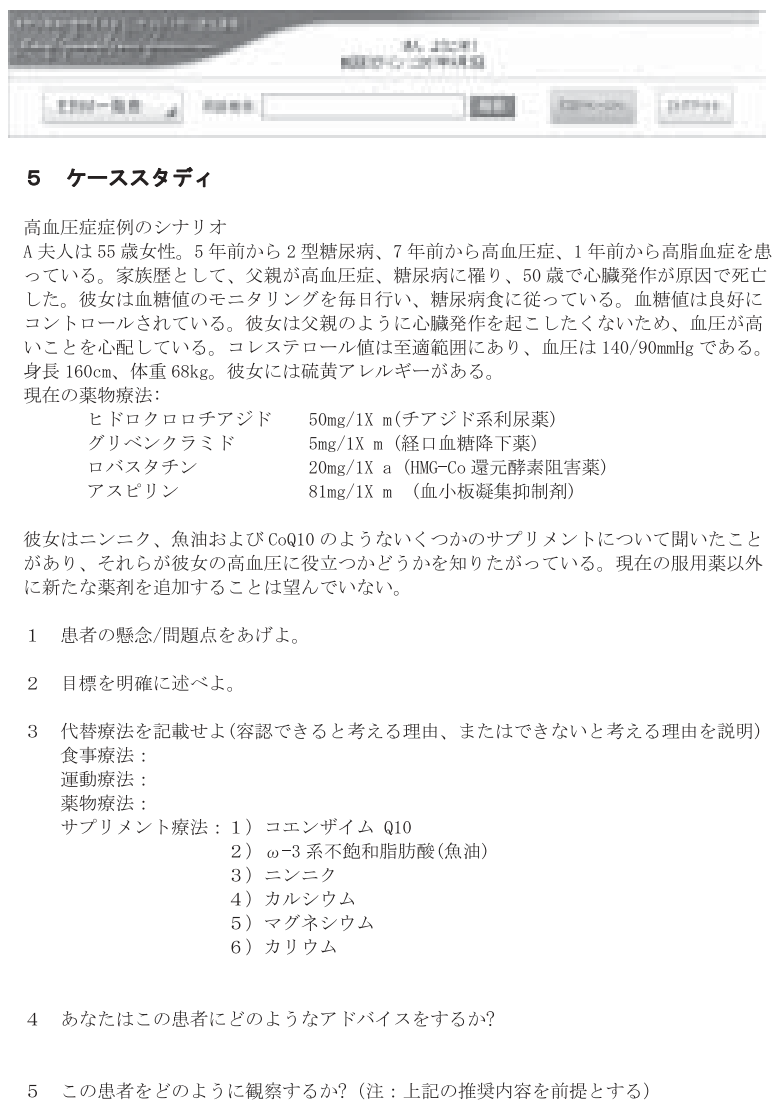

图 4 疾患別に打ける代替医療を含めた全体的な医療方針の決 定

各疾患別に通常の医療や代替医療を含めた総合的な医療方向性 を症例シミュレーション的に思考している.

\section{V. 資格認定と登録}

\section{(1) NHP インターナショナル認定機構による資格認定}

自然食品やハーブといった，ある程度の薬理効果等を 持った食品などは Natural Health Products (NHP) と呼ばれ ることがある.このような NHP は日本では薬品としての 扱いを受けているわけではないが，これまで示したよら に薬理効果を持ち, 医療としての補助や病気予防として 利用されることがある。

このような NHP に対する臨床的な観点からの知識の 習得や普及活動を目的として, NHP インターナショナル 認定機構（特定非営利活動法人）を設立した. この NPO 法人をとおして，より多くの臨床的立場の人々に NHP, すなわちサプリメントを含む食品物や成分の知識を習得 していただきたいと考えている。そしてそれらの知識を 得た医療従事者がリーダーとなり，予防医学の領域に至 るまで多くの方の健康管理に役立てていくことが，今後 の日本に拈いて必要になっていくことであろら.

今回紹介した MSA 認定講座は MSA（メディカル・サ
プリメント・アドバイザー）といら認定資格を取得させ ることを目的として作られた講座であるが, MSA は国家 資格のようなものではない.しかし客観的な評価基準を 作り，一定の知識を習得したと判断されたものに対して NHP インターナショナル認定機構に入会いただき, MSA の資格認定することとした．資格取得後も会員として資 格を維持している間は，臨床試験のアップデート情報と いった新しい情報の入手や，ウェブ講座の継続的な利用 により, サプリメントに関して常にアクセスしやすい環 境を維持することができる。こうした活動を通して多く の医師や薬剤師を中心に医療現場で活躍し，意識の高い 優秀な人材を育成できると考えている.

\section{(2) CBT 試験システム}

NHP インターナショナル認定機構はMSAの資格認定 を行らに際し，適当で杜撰なものとなってはならない. しかし受講者の多くが，すでに臨床の場で活躍されてい る多忙な医療従事者を対象としていることも考慮する必 要がある.

この MSA 認定講座も受講者の利便性を考え e ラーニ ングで行われていることから, 認定試験についても考慮 する必要があった。しかし，こらいったインターネット を利用した講座では厳正な試験が行われているかは大き な問題となっていた，その点を考慮して当機構では Computer Based Testing (CBT) システムを採用している. このシステムは全国にいる受講生に対する認定試験とし て，比較的近くの試験会場で適正な試験を受けていただ くためのものである、全国の各都道府県にわたり，合計 100 箇所以上の試験会場が全国にある. 認定試験の受験 の際には，いつでもどの会場でも試験を受けることが可 能になった．このときに本人であることを敛密に確認さ せていただくためのチェックが行われるのはもちろん, 試験会場内では各人が利用するコンピューターにその受 験生のみに与えられる試験が行われる。試験内容は認定 試験用に作成された難易度の調整された試験問題されて おり，個々の受験生に対してランダムに選ばれて出題さ れる。したがって公正性に優れた試験がいつでもどの地 域でも行われるよらになった。

こうして適切な知識の習得により, 資格認定としてあ るレベル以上であることを認定機構が判断したものに対 して MSA の資格認定を行らといらシステムをとってい る. 


\section{VI. 健康に関する社会の变化と医療機関側の今後の対応}

\section{(1) サプリメント社会の増大}

昨今，多くのテレビ番組や雑誌等でも医療関連や健康 関連のものが増光, 日本国民に打ける健康や病気予防に 対する意識は以前よりはるかに高まってきている，その 意識対象者は病気の患者や家族だけでなく，一般の方た ちの健康志向にも及ぶ.

こういった健康志向の媒体となるものは，内容的には 東洋医学的なものから, 音楽・芸術といった心理的な側 面から入るもの，さらには食事・栄養療法から温泉療法 などまで多岐にわたる，その中でサプリメントはその代 表であり，多忙な社会生活の中でも薬のように服用する だけといら簡便性とメディアを通した販売宣伝効果か ら，さらに人気を集めている.

現在日本に拈けるサプリメント関連人口は急激に増大 している.サプリメントに関心があるか，または服用し ている人を含めると，日本国民の $70 \%$ を超えると言われ ている。 またサプリメントを含む健康に関連する市場規 模は数千億円から数兆円規模になっている. サプリメン ト大国のアメリカも日本を大きな市場として考え, 次々 と進出してきている。すずに 7 割といわれているサプリ メント利用者は今後さらに増加するだけでなく，使用量 が増大していくことが予想される.

こういったことを考觉れば，今後医師自身のサプリメ ントに対する認知の有無にかかわらず，国民の健康に責 任ある立場として, 何らかの対応が要求されることは避 けることができないであろら。そして，あまりにもいい 加減な「大丈夫でしょら」といった対応をとり，もし有 害事象が括こった場合，相談を受けたといら事実が残っ ていれば医師側のリスクにもなりらることも否定できな い. そらいったことからも, 健康食品やサプリメントに 対しては安易な返答は慎むべきだと思われる。しかし， ある程度の知識を持ち適切な指導を行えば, サプリメン ト利用者に対し大きな安心感を与え, 適切な健康管理に つながると考えられる。

今後の日本に打矤療の在り方を考えれば，医師を 含めた医療関係者が，このような環境を含めた健康管理 をすべく，まずはサプリメントの知識を持つこと，さら にネットワークを持つことなどが重要になると考えられ る.

\section{(2) 医療機関としての望ましい対応}

この MSA 認定講座を実際に受講してみると，講座内 容が高度であることに医師や薬剤師の方は少し驚かれる かもしれない. 特に一般的な日常の診療業務を行われて
いる医師は，その病態薬理学的な説明内容を理解しょう とすると，昔の教科書を取り出したくなるよらなものも 多く含まれている.

私が臨床医にとってサプリメントの知識の必要性を感 じていることはすでにご説明したが，しかしながら医師 皆がサプリメントの専門家になることは必要ではないと 考えている。一般の医師を含めた医療従事者にまず必要 なことは，サプリメントに対する悪い先入観をなくし， Natural Health Products に対して一定の理解を持つことで ある。そして正しい認識を持ちつつ，サプリメントに関 する知識をいつでも利用できる環境を作っておくことが 必要であると考学る。しし医師自身が専門化レベルの知 識を持てば，それは大きな診療上の武器となり，サプリ メント専門としても診療が可能なことであろう。

しかし，日常診療上では臨床上でのサプリメントの概 念を認識し，かつ知識を十分習得したパラメディカルの 協力があれば十分に対応は可能である。重要なことは， サプリメントを含めた診療の方向性を医師がリードしな がら決めていくことである。その決められた方向性にし たがい，パラメディカルの MSA が説明するよらな医療 環境がそろえば，望まれた健康指導を行らことができる のではないかと考学る。今後医師を中心として，サプリ メントの専門知識を持ったパラメディカルも㕕成し，病 気予防・健康維持を含めた健康管理に医師と医療機関が 総合的に対応できるようになることが望まれる。

この MSA 認定講座は 2006 年より開始された。開始し て 1 年程度であるが受講者は 2 割が医師で， 6 割 5 分が 薬剤師，残りがその他の医療資格者といら状況のようで ある、サプリメントに対する偏見のような意識は医師・ 薬剤師ともに強くあるようだが，医師に打ける偏見のほ らが強いように感じる，今後医師にもこのような講座を 多く受講された上で，サプリメントに関する正しい意見 を多くの方に述べていただけるように望も.

\section{VII. 終わりに}

この MSA 認定講座は日本補完代替医療学会の学識医 制度における資格更新の認定単位の一つとして認められ ている．多くの本学会会員の方に受講していただき，サ プリメントを含めた診療行為に利用していただきたいと 思う。

しかし，日常診療上の医師が持つべきサプリメント知 識は専門家になるためのものでなく，パラメディカルを 含めた医療環境のリーダーになることである。そのため には本講座は興味を持っている方以外にはやや荷が重い 気がするのも確かである。そこでもし医師からのご要望 
が多いよらであれば，上記の医師用の目的として本講座

を短時間で効果的に受講できる医師用特別版の e ラーニ

ング版の作製を提案しており,できることなら実行した

1) http://hfnet.nih.go.jp/

いと思っている. 私自身も特別版の作製を希望して打り,

2) http://kokusen.go.jp/

多くの方のご意見やご要望を賜ることができれば甚大で

3) http://www.e-msa.co.jp/

あると考えている.

\author{
ABSTRACT \\ for Physicians and Paramedical Staff \\ Keishi TANIGAWA ${ }^{1,2}$ \\ ${ }^{1}$ The director, Bio-Thera. Clinic \\ ${ }^{2}$ The chairperson, Association for NHP International Accreditation
}

\title{
A Recommendation for the Acquisition of Knowledge of Natural Health Products (NHP)
}

The number of people that use Natural Health Products (NHP), not only as a complementary medical treatment, but also for disease prevention and health maintenance, has increased considerably in recent years. Although classified as a food, NHPs can have various pharmacological effects, leading to situations that cannot be ignored by healthcare administrators. However, the level of knowledge and awareness of NHPs are inadequate among healthcare professionals. The Medical Supplement Advisor (MSA) Certification Course that is introduced here is an advanced level course intended for medical professionals only, which examine NHPs, categorized by specific diseases, based on EBM. The contents and arrangement of this course allow clinical physicians and pharmacists to learn and acquire more effectively the knowledge and tools of NHPs and has also been designed with special attention to the clinical application of that knowledge. In order to maximize convenience, the entire course is offered on-line and a CBT system is utilized for the qualification exam. It is essential for healthcare administrators in the future to be able to critically assess information about NHPs and to play a guiding role in health management programs and comprehensive medical care that incorporate Natural Health Products.

Key words: Medical supplement advisor (MSA), Supplement, Natural Health Products (NHP), e-learning system, Computed Based Testing system (CBT system) 